\title{
Biogas in Brazil: A Governmental Agenda
}

\author{
Melissa Cristina Pinto Pires Mathias ${ }^{1}$ and João Felippe Cury Marinho Mathias ${ }^{2}$ \\ 1. Department of Mechanical Engineering, Pontifícia Universidade Católica, Rio de Janeiro 22,451-900, Brazil \\ 2. Institute of Economics, Federal University of Rio de Janeiro, Rio de Janeiro 22,290-240, Brazil
}

Received: March 20, 2014 / Accepted: May 04, 2014 / Published: January 31, 2015.

\begin{abstract}
Environmental issues have become an important aspect in the energy sector and also in governmental policies all over the world. Renewable energy plays a decisive role in a cleaner energy production with less environmental impacts. In this new world scenario, several countries create incentive programs aiming to increase the renewable energy share in their energy balance. Biogas is an interesting example of a smart and rational use of organic waste material. Nevertheless, international experience shows that its production relays mainly on government incentives. This paper investigates what the Brazilian government role is to introduce and promote the biogas industry in the country. We estimate the production of agricultural waste energy using biogas derived from cattle and swine waste and analyze the Brazilian legal and regulatory framework for renewable energy, focusing on biogas production, transport and sale. The results point to an unexplored potential of the use of cattle and swine waste for biogas production in Brazil. However, this potential can only become a reality if some legal and regulatory issues are solved. Brazilian government agenda has to include not only filling the legal and regulatory blanks but also creating incentives for the use of biogas.
\end{abstract}

Key words: Biogas, renewable energy, policy, Brazil.

\section{Introduction}

The relationship between energy and economic development is widely known and discussed. In fact, there is extensive literature that associates economic growth with consumption of electricity and other energy sources and discusses the causal relationship between energy and economic growth. Despite the knowledge about the impact and external factors generated by energy use and production, there is an increasing demand for energy and, in order to meet this growing demand, investments must be made to allow an increase in energy supply, taking into account not only the amount of energy that is generated, but also the impact on society and the economy.

Brazil has already produced a large amount of energy from renewable sources, mainly from hydropower plants $(81.9 \%$ in 2011 , according to the

Corresponding author: Melissa Cristina Pinto Pires Mathias, professor, research fields: natural gas, biomethane and regulation. E-mail: mmathias@puc-rio.br.
Brazilian Energy Balance 2012 [1] $)^{1}$. However, there is enormous potential for the use of other renewable sources of energy, such as solar energy, wind power, and sources generated from organic biomass. In order to encourage the use of renewable energy sources other than the large hydropower plants to produce electricity, in 2002, the Brazilian Government passed a law creating a policy called PROINFA (Incentive Program for Renewable Energy Sources). This policy program aims to push the development of renewable energy (wind, biomass, and small hydro).

As a result of PROINFA, there has been a considerable increase in the supply of electricity generated by wind ${ }^{2}$

\footnotetext{
${ }^{1}$ In 2011, according to Ref. [1], domestic electricity supply by source in Brazil was: $81.9 \%$ (hydro); $6.6 \%$ (biomass); $0.5 \%$ (wind); $4.4 \%$ (natural gas); $2.5 \%$ (oil products); $2.7 \%$ (nuclear); $1.4 \%$ (coal and coal products).

${ }^{2}$ According to Ref. [1], the production of electricity from wind power reached 2,705 $\mathrm{GWh}$ in 2011 . This represents a $24.3 \%$ increase over the previous year, when it reached 2,177 GWh. According to Ref. [2], a turning point for windpower development in Brazil was the renewable energy incentive program (Proinfa) of the Ministry of Mines and Energy, established in 2002. The installed capacity for wind power rose from $56 \mathrm{GWh}$ to 2,705 GWh between 2002 and 2011.
} 
and biomass. According to data from the Ministry of Mines and Energy, until December 31, 2012, 19 biomass plants, 41 windpower plants, and 59 SHPs (small hydropower plants) had been founded. The biomass energy projects are associated mainly with sugarcane vinasse. The use of other forms of biomass, such as landfills and animal waste, still has very limited participation in the country's energy supply [1]. The use of organic biomass has the advantage of not only generating energy (heat and electricity) but also reducing the environmental impact associated with the disposal of this biomass. Therefore, there is a dual environmental advantage: waste reduction and renewable energy generation.

Nevertheless, there are great obstacles to the implementation of the use of biomass for power generation in Brazil, mainly the fact that the residue is spread out over a territory of continental proportions. In addition, investments are generally small and decentralized, which minimizes the advantages of credit access. There is also the need to reconcile the interests of distributing companies (aimed at maximizing the number of clients) and those of potential users of the energy generated by organic biomass (who will not only leave the distributing companies but may also become potential suppliers of the future energy surplus).

Among the alternative uses for biomass, residue is biogas production, which can be used directly or transformed into electricity. In either case, the use of biomass to produce energy represents distributed generation, as the source of the energy production is close to the consumer. In Brazil, there is a great potential for various types of biogas production, particularly sugarcane vinasse, urban waste (including solid waste from landfills and liquid waste from effluent treatment plants), and cattle and swine waste. Ref. [3] estimates that the potential for electricity generation from different sources of biogas in Brazil is between $1.21 \%$ and $1.30 \%$ of the installed capacity and concludes that there is a great potential for power generation from biogas obtained from the anaerobic digestion of organic residue. In fact, given the variety of possibilities for biogas production, their heterogeneous nature, and their geographical dispersion in the territory, each of these possibilities must be analyzed taking into account their peculiarities and characteristics with regard to socioeconomic contribution to the country and to their local area.

As previously mentioned, alternative energy sources generally have one element in common: they are considered distributed generation with decentralized, small-scale energy production, unlike the conventional style of energy production, which in Brazil's case is concentrated in large hydropower plants or in enterprises with great installed capacity. Distributed generation still faces resistance from the industry's planners and operators, one of the reasons being the complexity of managing the quality and quantity of energy needed to supply large demands with numerous small-scale energy sources scattered throughout the territory [4]. However, there are also benefits to be considered, particularly the avoided cost of enterprises in electricity generation and transmission (or gas transportation), as energy is generated in the location where it is consumed.

The process of distributed generation from waste biomass involves the transformation of waste into biogas with the use of biodigesters (for a detailed description of the process that takes place in biodisgesters (see Refs. $[5,6])$ ). This biogas can be used directly or to produce electricity. In both cases, the energy produced can be used for private consumption and the excess can be sold to distributors of natural gas or electricity, respectively. In the case of cattle and swine waste and sugarcane vinasse, given their agricultural nature, one of the by-products of this process is biofertilizer, which makes its use even more advantageous. In fact, the concept of agroenergy is being consolidated in connection with the idea of distributed generation.

This consolidation of agroenergy as an officially 
recognized and stimulated economic activity gives rise to a new business and a new source of income for rural properties in addition to the revenue generated by traditional agricultural products. Through the structure of prices, periods, and firm long-term contracts with publically regulated official distributors, agroenergy constitutes new perspectives in the field [7]. The development of biogas systems is inserted in this context. Thus, sustainability in the current model of rural production in Brazil becomes viable with the inclusion of agroenergy in rural properties, based on the technology of environmental sanitation through the treatment of residual biomass in biodigesters, which allows the exploitation of the potential for energy generation with the use of the concept of distributed generation [8].

Given the range of possibilities of biogas generation, the present article estimates the potential production derived from cattle and swine waste. The intention is not to exhaust the topic of biogas in Brazil, but to measure the potential production using animal waste and to propose a list of actions that can be implemented by the government to encourage the development of the country's biogas systems. The work is based on the hypothesis that the country has enormous potential for biogas production and use, but it lacks political tools, such as a more focused legislation that would facilitate the development of biogas systems. It is worth noting that biodigester technology is available, however, the greatest barriers do not seem to be technological but political and regulatory in nature.

To provide a glimpse of the potential for biogas production in Brazil, the article analyzes one of several possible sources of biogas: the biomass derived from cattle and swine waste. Swine and confined cattle production is very relevant in the country's rural areas, and the effective use of the biogas generation potential would contribute to sustainability in these areas. In general terms, the aforementioned activity generates residue that poses a high risk of environmental pollution primarily due to its great amount of nutrients and biodegradable organic materials, which can contaminate the soil and ground water and reach superficial bodies of water.

To achieve the proposed objective of assessing the potential of biogas generation from cattle and swine waste and identify the political and regulatory barriers that open a government agenda on the subject, this work is divided into four more sections: the methodological aspects are presented in Section 2, followed by the state of the art of biogas in Brazil and an estimation of the potential for biogas generation from cattle and swine waste; Section 4 lays out the governmental agenda for biogas development in the country; finally, the final considerations are presented.

\section{Methodological Aspects}

Biogas is produced when microorganisms break down organic materials in the absence of oxygen, also called anaerobic digestion. The biogas produced consists of methane (50\%-80\%), carbon dioxide (20\%-50\%), and traces of hydrogen sulphide (0-0.4\%), for example [6]. The biogas can be used for different energy services, such as heat, CHP (combined heat and power), and vehicle fuel, although the latter requires upgrading, by which most of the carbon dioxide and the hydrogen sulphide are removed. Additional treatment (to achieve local specifications) will also allow injection into the natural gas grid. The various sources of organic biomass are converted using biodigesters and can have different energy uses. Fig. 1 presents a simplified flow diagram of a generic anaerobic digestion plant based on organic feedstocks.

Biogas digesters have come to symbolize access to modern energy services in rural areas and are slated to considerably improve health and sanitation, and to yield significant socioeconomic and environmental benefits [5]. In order to identify the possibilities of the use of biogas in Brazil, as well as the political and regulatory challenges for the development of biogas systems in the country, we will conduct a literature review and statistical analysis that will allow the 
estimation of the potential for biogas generation from cattle and swine waste. The literature review will describe the state of the art of biogas in Brazil and point out the indicators that will be used to estimate the biogas potential. A study of the international experience, notably the cases of China and India, given their similarities with Brazil, can provide information on how the implementation of biogas took place in these countries and give examples that can be adapted and incorporated into the Brazilian reality.

The most recent data on the amount of cattle and swine waste in the country are found in the Agricultural and Livestock Census of 2006 (Instituto Brasileiro de Geografia e Estatística [10]). These data are invaluable to the study of the potential for biogas generation from the biomass derived from animal waste. Moreover, they help to corroborate the theory that there is no dissemination of management systems for the treatment of animal waste, clearly indicating the environmental problem caused by agricultural and livestock activities. There is also important data on the incipient purchase and self-production of electricity by rural properties, which confirms the hypothesis of the potential for exploitation by the national agricultural industry.

Due to the need to delimit the study, more specific data will be used as described below:

- Agricultural and livestock management, which refers to the use of animal waste;

- Self-generation and purchase of electricity by the rural property, which represents the amount of energy that the rural property produces on site;

- Number of heads of cattle and swine, which will be the basis for the calculation of the biogas generation potential. The data on cattle only refer to confined cattle for the simple reason that intensive systems have access to the animals' waste.

The special supplement of the Agricultural and Livestock Census for Family Farming provides the following piece of data [11]:

- Participation of family farming in cattle and swine raising, which represents the number of small scale properties in the production of swine and confined cattle. These data provide the dimensions of small and large scale properties and are useful in the development of policies suited to each type of property.

With the total number of swine and confined cattle, it is possible to estimate the production of biogas based on waste/animal/day indicators. Therefore, the following additional data are required:

- indicators for estimation of solid cattle and swine waste generation;

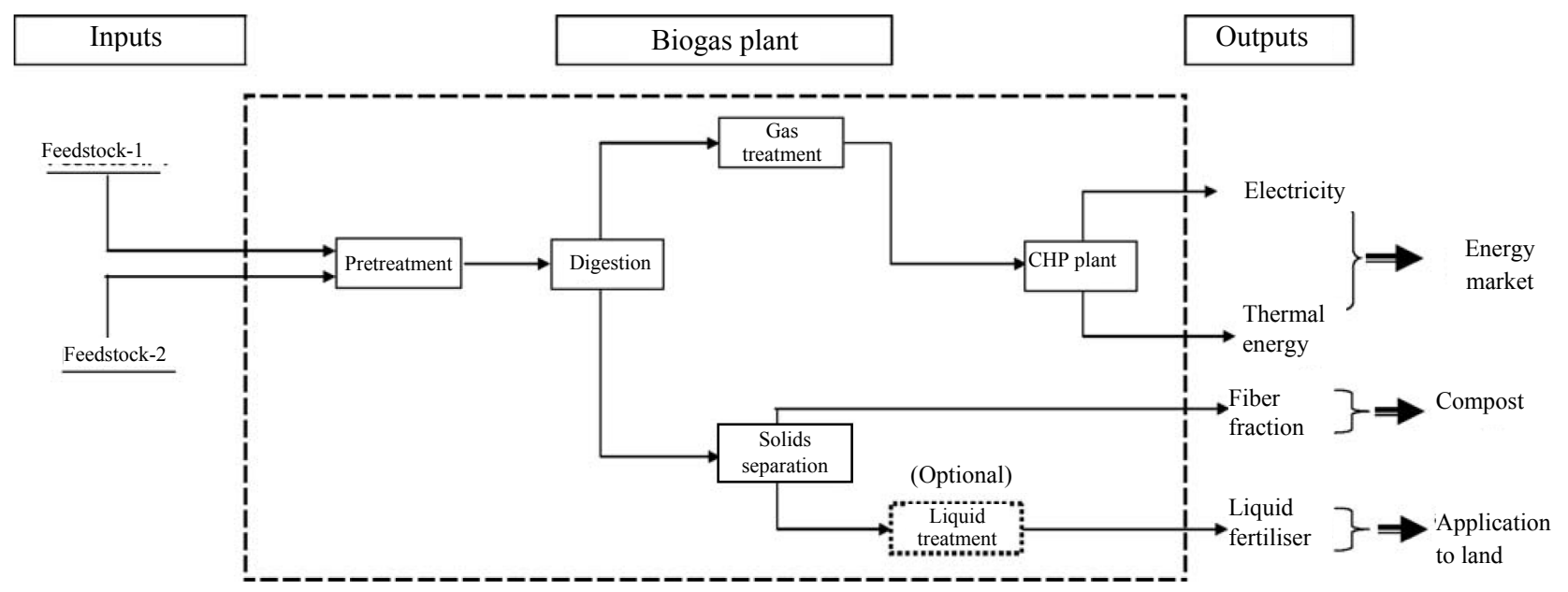

Fig. 1 Simplified flow diagram of a generic anaerobic digestion plant based on organic feedstocks. Source: Karellas, Boukis \& Kontopoulos (2010: 1274) [9]. 
- indicators for conversion of cattle and swine waste into biogas (biomethane).

Finally, we will analyze the legal framework related to the production and use of biogas in the country. For that, we will present and discuss the laws, decrees, and regulations related to biogas.

\section{In Search of an Alternative Source of Fuel: The Potential of Biogas Derived from Organic Biomass}

This section aims to show evidence of the potential for biogas generation from cattle and swine waste, starting with a brief state-of-the-art review on biogas in Brazil.

\subsection{The State of the Art of Biogas in Brazil}

Just over 30 years ago, Brazil fostered a program to introduce biodigesters in rural areas; however, it did not bring significant investments for the use of residual biomass. In light of this unfulfilled expectation, official efforts to stimulate waste treatment with biogas generation and energy use gradually decreased. However, in some regions, notably the southern region, farmers continued the process on their own [7].

Despite the negative experience with electricity production from residual biomass, recent incentive programs for renewable sources, such as PROINFA, have been successful, as in the case of wind power [2]. This program was established by Law 10438 of April 26, 2002 and updated by Law 10762 of November 11, 2003. It aims to diversify the national energy grid and find regional solutions with the use of renewable energy sources, through the exploitation of available raw materials and applicable technologies, starting with an increase in the participation of the electricity derived from these sources in the National Interconnected Electrical System (Sistema Elétrico Interligado Nacional-SIN).

One of the sources included in the PROINFA program is biomass. However, in the case of biomass, there are only projects related to sugarcane vinasse. In Brazil, there is practically no treatment of cattle and swine waste and it receives no benefits from PROINFA. This calls for an investigation into the reasons behind the non-use of the potential for biogas generation from animal waste.

The literature indicates that the biogas production initiatives in Brazil are incipient and isolated. In reality, renewable energies in general are still classified as "alternative", which renders them inferior to hydropower, and still considered the noblest renewable source [7]. Sector statistics ignore the energy potential of organic residues, if not for the purposes recorded in the distribution of spaces of the so-called alternative energies, then at least for the correct identification of the economic potential that these residues and effluents represent to their generators. One of the most concrete examples of biogas production incentives in Brazil is that of the Itaipu Renewable Energy Platform (http://www.plataformaitaipu.org/energia/biomassa), which has several demonstration units in the state of State of Paraná. Among its success stories is Condomínio Ajuricaba, a cooperative of small-scale cattle and swine producers that generate approximately $1,000 \mathrm{~m}^{3} /$ day of biogas.

As previously mentioned, the use of biogas as an energy source represent distributed generation. In addition to the advantages related to avoided cost with investments in generation and distribution, distributed generation allows energy consumption (thermal or electrical) along with production. In the case of biogas, there is the possibility of use in energy-intensive industries, such as the grain, brick, cement, tile, stone and other mineral product industries, as well as packing plants, mills, and other agricultural industries. Therefore, these segments can find in biogas actual possibilities of obtaining energy that is custom-made for their high consumption [12].

Even though initiatives for biogas generation from animal waste are isolated, there is a significant 
potential for it in Brazil's rural areas, particularly in cattle and swine farms. The Southern Region has characteristics that are very favorable to the development of biogas systems, given that it holds a large part of the cattle and swine production. Data from the IBGE Agricultural and Livestock Census show that biogas production is practically non-existent in rural areas and those rural properties depend on the electricity purchase from distributors. It is also evident that there is no adequate treatment of animal waste, which leads to a significant environmental problem.

Table 1 shows the electricity purchased by rural properties and obtained by assignment, and Table 2 shows the total electricity produced in rural properties.

In 2006, the Agricultural and Livestock Census counted 5,175,489 agricultural and livestock establishments, of which $68.1 \%$ or $3,526,330$ units obtained electricity from at least one source. Electricity purchase from distributors is presented in $3,258,676$ properties (about $92.4 \%$ of the total with energy); electricity obtained by assignment is presented in $7.7 \%$; and electricity generated in the property is presented in $2.1 \%$ or 75,457 properties.

When the data from Tables 1 and 2 are compared, it is possible to see that a very small number of establishments generate their own electricity, most of which used solar energy or burned fossil fuels in 2006.
Therefore, there is room for the development of biogas systems in Brazil and particularly the Southern Region, where intensive production is very significant and where most of the heads of swine and cattle are concentrated. In addition to the previous argument, there is the fact that only a few properties have adequate treatment for manure, as shown in Table 3 .

Not only is there a small number of properties with waste treatment, but most of them use treatment in open tanks. Treatment in biodigesters was insignificant in 2006. A simple data analysis shows that there is room to adopt policies that allow the treatment of animal waste with simultaneous generation of biogas and biofertilizer. Ref. [13] clearly summarizes the importance of animal waste treatment:

"The employment of anaerobic digestion technology for waste treatment is possible and desirable given that it contributes to environmental conservation, makes modern production systems viable, and optimizes the enterprise's cost/benefit ratio, etc.. In the same way, rational use of raw material and correct waste management optimize productive systems to achieve a harmonious coexistence between man and the environment".

In fact, generation of biogas from the anaerobic digestion of biomass is a technology that can produce sustainable energy and also reduce the environmental

Table 1 Electricity used by establishments, Brazil and Southern Region, 2006.

\begin{tabular}{lll}
\hline Brazil and Southern Region & Purchased & Obtained by assignment \\
\hline Brazil & $3,258,676$ & 270,293 \\
Southern Region & 812,468 & 33,144 \\
State of Paraná & 270,084 & 19,667 \\
State of Santa Catarina & 175,379 & 3,217 \\
State of Rio Grande do Sul & 367,005 & 10,260 \\
\hline
\end{tabular}

Source: IBGE, Agricultural and Livestock Census of 2006.

Table 2 Total electricity used and generated within the establishment, according to source, Brazil and Southern Region, 2006.

\begin{tabular}{llllll}
\hline Brazil and Southern Region & Solar energy & Wind power & Hydropower & Burning fuels & Other source \\
\hline Brazil & 32,217 & 273 & 7,072 & 30,669 & 6,321 \\
Southern Region & 308 & 28 & 796 & 464 & 538 \\
State of Paraná & 106 & 7 & 287 & 126 & 232 \\
State of Santa Catarina & 56 & 5 & 143 & 50 & 101 \\
State of Rio Grande do Sul & 146 & 16 & 366 & 288 & 205 \\
\hline
\end{tabular}

Source: IBGE, Agricultural and Livestock Census of 2006. 
Table 3 Treatment of manure per establishment, Brazil and Southern Region, 2006.

\begin{tabular}{lllllll}
\hline $\begin{array}{l}\text { Brazil and Southern } \\
\text { Region }\end{array}$ & $\begin{array}{l}\text { Total } \\
\text { properties }\end{array}$ & $\begin{array}{l}\text { Treatment in } \\
\text { anaerobic lagoon }\end{array}$ & $\begin{array}{l}\text { Treatment in } \\
\text { open tanks }\end{array}$ & $\begin{array}{l}\text { Treatment in } \\
\text { biodigester }\end{array}$ & $\begin{array}{l}\text { Treatment with } \\
\text { composting }\end{array}$ & $\begin{array}{l}\text { Treatment } \\
\text { elsewhere }\end{array}$ \\
\hline Brazil & $5,175,489$ & 3,269 & 131,232 & 2,387 & 31,849 & 27,197 \\
Southern Region & $1,006,181$ & 1,618 & 82,609 & 1,223 & 21,379 & 7,877 \\
State of Paraná & 371,051 & 490 & 13,036 & 393 & 6,271 & 3,043 \\
State of Santa Catarina & 193,663 & 529 & 28,016 & 490 & 7,823 & 1,478 \\
State of Rio Grande do Sul 441,467 & 599 & 41,557 & 340 & 7,285 & 3,356 \\
\hline
\end{tabular}

Source: Mathias (2014) [14].

risks associated with manure and waste management [15]. The first conclusion drawn from the analysis of the previous tables (Tables 1-3) is that, if the deficiencies of Brazil's rural areas were addressed with biogas systems, there could be immediate benefits from an economic perspective (at the very least energy generation for private consumption and biofertilizers) and from an environmental perspective (animal waste treatment). The potential for biogas generation from animal waste is shown in the next section.

\subsection{Potential for Biogas Generation from Animal Waste}

In this section, we estimate the potential for the generation of biogas derived from cattle and swine waste. As highlighted in Section 2, the methodology used to obtain this estimate is based on data from the most recent Agricultural and Livestock Census (2006) published by IBGE, which shows the structural data of Brazilian agriculture and livestock production. The information needed to obtain the estimates for animal waste and, consequently, biogas production refers to the total heads of swine and cattle. In the case of swine, the information of interest is the total number of heads and, in the case of cattle, the number of confined animals, as the objective is to obtain biogas from dry animal waste, which is not possible in extensive cattle farming.

The data from the Agricultural and Livestock Census [10] included in Table 4 shows the number of swine in the country in 2006, which exceeded 31.1 million heads, more than half of them (16.7 million) concentrated in the Southern Region. Although the number of heads of cattle is far greater (nearly 200 million), only confined animals can be considered for the potential of waste generation, which exceeded 4 million heads in 2006 including a little over 600 thousand heads in the Southern Region.

With the number shown in Table 4 and the estimates of daily production of dry material from swine and cattle waste, it is possible to calculate the potential for waste production in tons/day. Considering that swine produce $2.3 \mathrm{~kg}$ to $2.5 \mathrm{~kg}$ of dry waste per day and that cattle produce $10 \mathrm{~kg}$ to $15 \mathrm{~kg}$ per day [3], it is possible to obtain the values expressed in Table 5 . The extremes are both scenarios considered in this study, with Scenario 1 being the lowest and Scenario 2 being the highest.

Based on daily waste production, we can calculate the potential for biogas generation in Brazil and particularly in the Southern Region. The indicator for conversion of animal waste into biogas, more precisely methane gas $^{3}$ is provided by Ref. [16]: for beef cattle, $40 \mathrm{~m}^{3}$ of methane gas per ton of dry material and, for swine, $350 \mathrm{~m}^{3}$ of methane gas per ton of dry material ${ }^{4}$. Thus, we have the estimate for the potential for methane gas production (Table 6).

\footnotetext{
${ }^{3}$ The typical composition of biogas is predominantly $\mathrm{CH}_{4}$ (methane gas), which represents between $55 \%$ and $75 \%$ of biogas. Another important gas that is generated is $\mathrm{CO}_{2}$, with a participation of $25 \%$ to $45 \%$ in biogas [9].

${ }^{4}$ The data from Ref. [16] are close to those seen in international experience. Ref. [9] provides an indicator of $362.5 \mathrm{~m}^{3}$ of $\mathrm{CH}_{4}$ per ton of dry material for swine. When measured in $\mathrm{m}^{3} /$ animal/day, Ref. [17] provides an indicator of 1.43 $\mathrm{m}^{3} /$ animal/day for swine and $0.32 \mathrm{~m}^{3} /$ animal/day for cattle. However, this refers to the indicator for biogas production and not specifically methane gas. In that case, the data from Ref. [17] are similar to the data from Ref. [18], which show indicators for biogas production from dry material from cattle and swine $\left(1.40 \mathrm{~m}^{3} / \mathrm{animal} /\right.$ day $)$ in Brazil.
} 
Table 4 Number of heads of swine and confined cattle, Brazil and Southern Region, 2006.

\begin{tabular}{lllll}
\hline \multirow{2}{*}{ Region and states } & \multicolumn{2}{c}{ Swine } & \multicolumn{2}{c}{ Confined cattle } \\
\cline { 2 - 5 } & Number of establishments & Number of heads & Number of establishments & Confined animals \\
\hline Brazil & $1,496,107$ & $31,189,339$ & 20,864 & $4,049,210$ \\
Southern Region & 451,870 & $16,750,420$ & 5,750 & 603,153 \\
State of Paraná & 135,477 & $4,569,275$ & 2,633 & 366,577 \\
State of Santa Catarina & 82,324 & $6,569,714$ & 1,299 & 77,104 \\
State of Rio Grande do Sul & 234,069 & $5,611,431$ & 1,818 & 159,472 \\
\hline
\end{tabular}

Source: IBGE (2007).

Table 5 Potential production of swine and cattle waste, Brazil and Southern Region, 2006 (tons/day).

\begin{tabular}{lllll}
\hline \multirow{2}{*}{ Region and states } & \multicolumn{3}{c}{ Swine } & Confined cattle \\
\cline { 2 - 4 } & Scenario 1 & Scenario 2 & Scenario 1 & Scenario 2 \\
\hline Brazil & 71,735 & 77,973 & 40,492 & 60,738 \\
Southern Region & 38,526 & 41,876 & 6,032 & 9,047 \\
State of Paraná & 10,509 & 11,423 & 3,666 & 5,499 \\
State of Santa Catarina & 15,110 & 16,424 & 771 & 1,157 \\
State of Rio Grande do Sul & 12,906 & 14,029 & 1,595 & 2,392 \\
\hline
\end{tabular}

Source: Prepared by author based on data from IBGE (2007).

Table 6 Potential for methane gas production. Brazil and Southern Region: 2006 ( $\left.\mathrm{m}^{3} / \mathrm{day}\right)$.

\begin{tabular}{lllll}
\hline \multirow{2}{*}{ Region and States } & \multicolumn{3}{c}{ Swine } & Confined cattle \\
\cline { 2 - 4 } & Scenario 1 & Scenario 2 & Scenario 1 & Scenario 2 \\
\hline Brazil & $25,107,418$ & $27,290,672$ & $1,619,684$ & $2,429,526$ \\
Southern Region & $13,484,088$ & $14,656,618$ & 241,261 & 361,892 \\
State of Paraná & $3,678,266$ & $3,998,116$ & 146,631 & 219,946 \\
State of Santa Catarina & $5,288,620$ & $5,748,500$ & 30,842 & 46,262 \\
State of Rio Grande do Sul & $4,517,202$ & $4,910,002$ & 63,789 & 95,683 \\
\hline
\end{tabular}

Source: Prepared by author based on data from IBGE (2007).

The data in Table 6 are very representative, given that in 2006 the country imported 26.8 million $\mathrm{m}^{3} /$ day of natural gas $(95 \%$ from Bolivia and 5\% from Argentina). In other words, if all of the swine and cattle waste in Brazil was treated in biodigesters, the potential for gas generation would meet the country's importation needs. In Brazil, particularly the Southern Region, there is a strong presence of small family farms, as seen in the data analysis of the Agricultural and Livestock Census of 2006. Based on the census, IBGE conducted a study on Family Agriculture in the country. The Institute used the concept of Family Agriculture defined by Law 11326 of July 24, 2006. According to the law, rural family units must meet the following criteria simultaneously: the area of the rural establishment must not exceed four modules for tax purposes; the labor employed in the economic activities must be predominantly from the family; the family income must come predominantly from these activities; and the establishment must be managed by the family [11].

Table 7 shows the participation of Family Agriculture in cattle and swine raising in the Southern Region in 2006.

From Table 7, it can be concluded that:

- The number of rural establishments is composed mainly of family units (between $81 \%$ and $90 \%$ );

- In the case of cattle, with the exception of the state of Santa Catarina, most of the herd belongs to non-family units; 
Table 7 Participation of family agriculture in cattle and swine raising, Southern Region, 2006.

\begin{tabular}{llllllll}
\hline \multirow{2}{*}{ State } & \multirow{2}{*}{ Activity } & \multicolumn{2}{c}{ Family agriculture } & \multicolumn{2}{c}{ Non-family agriculture } & \multicolumn{2}{c}{$\%$ family agriculture } \\
\cline { 2 - 8 } & & $\begin{array}{l}\text { Establ. } \\
\text { (number) }\end{array}$ & Heads & $\begin{array}{l}\text { Establ. } \\
\text { (number) }\end{array}$ & Heads & $\begin{array}{l}\text { Establ. } \\
\text { (number) }\end{array}$ & Heads \\
\hline \multirow{2}{*}{ State of Paraná } & Cattle & 171,618 & $3,161,405$ & 39,748 & $5,892,396$ & $81 \%$ & $35 \%$ \\
& Swine & 115,252 & $2,840,213$ & 20,225 & $1,729,062$ & $85 \%$ & $62 \%$ \\
State of Santa & Cattle & 129,254 & $2,038,705$ & 18,084 & $1,087,297$ & $88 \%$ & $65 \%$ \\
Catarina & Swine & 73,715 & $4,370,999$ & 8,609 & $2,198,715$ & $90 \%$ & $67 \%$ \\
State of Rio & Cattle & 283,768 & $4,063,020$ & 46,133 & $7,121,228$ & $86 \%$ & $36 \%$ \\
Grande do Sul & Swine & 209,282 & $3,942,427$ & 24,787 & $1,669,004$ & $89 \%$ & $70 \%$ \\
\hline
\end{tabular}

Source: Adapted from IBGE (2009).

- In the case of swine in all three southern states, most of the herd (between $62 \%$ and $70 \%$ ) belongs to family units.

Therefore, it can be concluded that the development of biogas systems, particularly small scale systems, can be a favorable strategy for local sustainable development. However, there are various challenges to be overcome before biogas can be produced on a large scale and not only in isolated local properties.

\section{Challenges to Biogas Development}

This section aims to present the pathways to the development of biogas in Brazil. First, some lessons will be learned from international experience that can contribute to the Brazilian experience. Next, some legal, political, and regulatory aspects are pointed out to show the need for a list of topics to be discussed and included in the governmental agenda.

\subsection{Lessons from International Experiences: The Cases of China and India}

Biogas production from animal waste is particularly useful in countries with swine and cattle herds and where the possible sites for residue use are geographically dispersed [19]. The reason for that is that locally produced biogas can be used in the farms themselves, whether for electricity generation for local supply (avoiding investments in the expansion of energy distribution networks to remote areas), for generation of thermal energy (useful in countries with harsh winters) or for drying grain (in farms with simultaneous cattle raising and production of foods that require thermal processes). If such farms are already connected to distribution networks of electricity or natural gas, the excess energy (electricity or methane, as long as specified) could be injected into the networks to increase the country's energy supply and reduce its dependence of possible energy importation and delaying the need for investment in energy generation and network expansion.

Given the similarities in the size of their territories and the large number of heads of cattle and swine, two of the most important developing countries that successfully use biogas systems can share their experiences and provide examples for Brazil to follow. These countries are China and India and, according to Ref. [20], they dominate the best technologies for the use of biodigesters. The main objective of the China is to obtain biofertilizers for food production, whereas, India seeks to reduce the energy deficit. The biodigester models are distinct: the Chinese is simpler and cheaper and the Indian is more sophisticated and technical to make better use of biogas production. The development of the technology of biogas in China and India is based on animal management, especially, swine and cattle raising [17].

Ref. [17] presents a history of biogas and assesses its future in developing countries, particularly China and India. According to the authors, starting in the 1970s, China promoted the use of biogas in all rural residences in the country. To cite an example, in 2007, there were 26.5 million biogas plants in China, mostly 
family systems producing $6-10 \mathrm{~m}^{3}$ of gas a day. Ref. [15] also presents an overview of China's biogas industry. However, they also emphasize how the management systems offer no adequate sanitation to prevent pollution. As a way of stimulating energy production from renewable sources, the Chinese government passed the "Renewable Energy Law" and provided incentives for biogas production in 2006. This shows that a country with ample reserves of hydrocarbons, particularly coal and more recently non-conventional natural gas, also has an interest in the use of biogas and other alternative energies.

As in China's case, India, with its vast territory and widely dispersed rural properties, granted government subsidies for the construction of 4 million family biogas plants between 1999 and 2007. Since the early 1980s, the country has run a project known as the NPBD (National Project on Biogas Development), which provides funding and training to the various development programs proposed by the government. These government subsidies for the development of family biodigesters covered $30 \%-100 \%$ of the total price of equipment between 1980 and 1990 [17]. Therefore, given their vast territories and the characteristics of their rural production, China and India are ideal countries for distributed generation of energy, particularly biogas production.

Undoubtedly, international experience suggests that the development of biogas systems requires a set of focused political measures with strong government participation, particularly with regard to the legal framework and the financial incentives provided ${ }^{5}$.

\footnotetext{
${ }^{5}$ Besides China and India, there are strong government incentives for biogas development in Europe, with Germany being the most emblematic example. The German case is particularly interesting for the analysis of an efficient policy for the development of alternative energy sources, especially the implementation of biogas production. In 2000, the country passed the Renewable Energy Source Act, which represents the foremost legal framework for the production of renewable energies, including biogas. Following the publication of this act, there was significant expansion in the production and consumption of renewable sources of energy in the country. According to Ref. [20], biogas production, in particular, showed extraordinary growth, with an eightfold increase
}

Another topic highlighted in international experience is the incentive for the development of small biogas plants in rural areas [19]. However, there are many political and legal obstacles to biogas development in Brazil that warrant a governmental agenda on the issue.

\subsection{Legal and Political Difficulties: A Governmental Agenda}

Ref. [7] believed that the legal conditions for bioenergy development had been given and all that needed was to stimulate its use. According to these authors, the legal conditions were given in two parts: legislation and policy programs. They are the following:

- Decree 5163 of July 30, 2004. This decree regulates electricity trading, the process of granting concessions and authorizations for electricity generation, and other provisions.

- ANEEL (National Electricity Agency) Normative Resolution 167 of October 10, 2005. This regulation defines the conditions for the trade of energy derived from distributed generation.

- Amendment to Law 9648/98 (Law 10438/02 included changes to article $11, \S 4$, regarding the system for subrogation of the cost of FFC (Fossil Fuel Consumption), which underwent several revisions and is currently regulated by ANEEL Resolution 146/05). This amendment allowed the transfer of FFC benefits, not only to SHPs as already prescribed by law, but also to wind, solar, and biomass sources implemented in isolated electrical systems to substitute thermal generation using petroleum by-products according to current and future demand, which simultaneously meets the process of universal access and introduction of alternative sources into the energy grid.

between 2000 and 2008 boosted by the strong development of biogas units in agricultural properties scattered throughout the country. In Germany, the primary purpose of biogas was electricity generation to replace the power originally derived from burning fossil fuels. In 2008, $15.1 \%$ of the total electricity consumption in Germany came from renewable sources, with $1.3 \%$ of the electricity coming from biogas. 
- PROINFA. This is a policy program for renewable energy generation. It was created by Law $10438 / 02$, which was a key step in shaping the legal framework for electrification efforts in Brazil ${ }^{6}$.

However, in September 2011, Brazil passed the Biofuels Law (Law 12.490/11), which can also be considered a new legal framework for biogas. This law made new contributions, but still left gaps that needed to be addressed to allow actual development of the activities related to the biogas system. According to Ref. [19], when it comes to biogas generation and distribution, there are still political and regulatory hurdles to be overcome. This reference points out that among other rulings, the Biofuels Law changes Law 9478/97 includes in "Principles and Objectives of the National Energy Policy": (1) the guarantee that biofuels will be supplied throughout the national territory; (2) incentives for electricity generation from biomass and by-products of biofuel production, given that it is clean, renewable, and complementary to hydropower; (3) the promotion of the country's competitiveness in the international biofuel markets; (4) the attraction of investments in infrastructure for transport and storage of biofuels; (5) the promotion of renewable energy research and development; and (6) the mitigation of greenhouse gas emissions and pollutants in the energy and transport sectors, including the use of biofuels.

The same law ruled that the National Council for Energy Policy must "define the strategy and the policy of economic and technological development of the oil, natural gas, fluid hydrocarbon, and biofuel industry, as well as its supply chain". It also defines the "Biofuel Industry" as a "set of economic activities related to the production, importation, exportation, transfer,

\footnotetext{
${ }^{6}$ Law 10438 obliges concessionaires and licensees to provide "universal electricity service coverage," without financial contribution by the new consumers toward initial investments (which are to be fully recovered through tariffs). However, the law was not a pure "rural electrification norm", as it covered a series of (competing) policy goals, namely rural access, power generation from alternative national resources (renewable energies, natural gas, and coal), social tariffs, and "emergency generation" [21].
}

transport, storage, trade, distribution, compliance assessment, and quality certification of biofuels" and "Biofuel Production" as a "set of industrial operations for transforming plant or animal renewable biomass into fuel". From the Law, it can be inferred that biogas derived from animal waste is classified as biofuel. According to natural gas Law 11909/09, however, the biogas extracted from animal waste cannot be classified as natural gas (despite their identical chemical composition) because the latter only applies to gas derived from petroleum or gas reservoirs. Nevertheless, biogas can be classified as biofuel if regulated as such by the National Agency of Petroleum, Natural Gas and Biofuels (ANP (Agência Nacional de Petróleo, Gás Natural e Biocombustíveis)).

Law 12490/11 ruled that it is the ANP's responsibility to "regulate and authorize activities related to biofuel production, importation, exportation, storage, stockpiling, transportation, transfer, distribution, resale, and trade, as well as compliance assessment and quality certification, inspecting them directly or in association with Union, State, Federal District or Municipal agencies". However, the Federal Constitution rules that it falls to the States to exploit the local piped gas services, regardless of source or composition. Thus, if the biogas derived from animal waste cannot be considered "natural gas", its local movement (within a Federal State) is state-regulated and not federally regulated. Nonetheless, there is legal provision that biofuel trade must be authorized by the ANP. In other words, the ANP is responsible for authorizing trade, but the state regulators are responsible for controlling the movement and sale to final buyers. Furthermore, when biogas is used to generate electricity, the activity is also regulated by ANEEL. Thus, a complex set of legal rules apply to biogas, from its production to its use.

Table 8 summarizes the legal framework that applies to the production, trade, and use of biogas and biogas-generated electricity.

This legal and normative framework assigns a 
number of duties and responsibilities to different public agencies of the energy sector, which are summarized in Table 9.

The analysis of the legal framework and the duties assigned to the different public agencies leads to the conclusion that this framework was developed in a hermetic fashion and did not consider the specificities of the biofuel industry. The different legal documents overlap duties, while also leaving gaps that need to be filled. One of the main juxtapositions is the role of regulating the direct use and trade of biogas. It is unclear whether it is a responsibility of the federal regulatory agency (ANP) or the state regulators. There is legal basis for both interpretations. One of the main gaps is the definition of biogas itself, which is not found in any of the normative frameworks provided.

The first topic on the governmental agenda for biogas is the clear definition of the duties of the State agencies regarding the production, movement, and use of biogas derived from animal waste, so that its development will not run into legal or bureaucratic matters that hinder the construction of an enterprise that could bring environmental and energy benefits to its area. Even without changes to the legal framework, it is fundamental to coordinate the public agencies in order to allow the development of biogas enterprises.

Table 8 Legal framework for biogas development in Brazil.

\begin{tabular}{|l|l|}
\hline Law/resolution/program & Description \\
\hline Law 10438 (PROINFA) & $\begin{array}{l}\text { Brazilian government policy aimed at promoting the expansion of distributed power generation } \\
\text { through renewable sources, and diversifying primary sources of electricity, thus improving the } \\
\text { long-term supplying conditions of the national system. }\end{array}$ \\
\hline Law 10762 & $\begin{array}{l}\text { Amendment to the previous law (Law 10438) to guarantee funds for anticipating deadlines } \\
\text { defined by regulatory agencies and to restrict the exemption of financial contribution to new } \\
\text { consumers with load up to 50 kW. }\end{array}$ \\
\hline Decree 5163 & $\begin{array}{l}\text { It regulates electricity trade and the process of granting concessions and licenses to generate } \\
\text { electricity, among other provisions. }\end{array}$ \\
\hline ANEEL normative resolution 167 & It defines the conditions for trading energy derived from distributed generation. \\
\hline Authorizing resolution 1482 & $\begin{array}{l}\text { It authorizes the Program for Distributed Generation with Environmental Sanitation proposed by } \\
\text { the Paraná State Energy Company (Companhia Paranaense de Energia-COPEL) as a pilot } \\
\text { project for implementing low-voltage distributed generation. }\end{array}$ \\
\hline ANEEL normative resolution 390 & $\begin{array}{l}\text { It sets the requirements for authorization to exploit and change the installed capacity of thermal } \\
\text { power plants and other alternative energy sources, describes procedures for registering } \\
\text { generation plants with reduced installed capacity, and makes other provisions. }\end{array}$ \\
\hline $\begin{array}{l}\text { Law 11909/09 } \\
\text { (Natural Gas Law) }\end{array}$ & $\begin{array}{l}\text { It provides the definition of "natural gas", which excludes biogas and prevents it from being } \\
\text { injected into the natural gas grid. }\end{array}$ \\
\hline $\begin{array}{l}\text { Law 12490/11 } \\
\text { (Biofuel Law) }\end{array}$ & $\begin{array}{l}\text { It deals with biofuels in general, but does not mention biogas explicitly. It rules that the ANP is } \\
\text { responsible for regulating the entire biofuel industry. }\end{array}$ \\
\hline
\end{tabular}

Source: prepared by the author based on Refs. [7, 19, 22].

Table 9 Public institutions of the energy sector and their duties.

\begin{tabular}{|l|l|}
\hline Agency & Legal responsibility \\
\hline $\begin{array}{l}\text { National Council for Energy Policy } \\
\text { (Conselho Nacional de Política } \\
\text { Energética-CNPE) }\end{array}$ & $\begin{array}{l}\text { To propose an energy policy that takes into account the rational use of the } \\
\text { country's energy resources, among other aspects; to define the strategy and } \\
\text { policies for the economic and technological development of the biofuel industry. }\end{array}$ \\
\hline $\begin{array}{l}\text { Ministry of Mines and Energy } \\
\text { (Ministério de Minas e Energia-MME) }\end{array}$ & To implement the energy policies proposed by the CNPE. \\
\hline $\begin{array}{l}\text { National Electricity Agency } \\
\text { (Agência Nacional de Energia Elétrica-ANEEL) }\end{array}$ & $\begin{array}{l}\text { To regulate electricity generation from biogas; to define the rules for the injection } \\
\text { of biogas surplus into the grid (sale to distributors). }\end{array}$ \\
\hline $\begin{array}{l}\text { National Agency of Petroleum, Natural Gas and } \\
\text { Biofuels (Agência Nacional do Petróleo, Gás } \\
\text { Natural e Biocombustíveis-ANP) }\end{array}$ & $\begin{array}{l}\text { To regulate and authorize activities related to biofuel production, importation, } \\
\text { exportation, storage, stockpiling, transport, transfer, distribution, resale, and trade. }\end{array}$ \\
\hline Statute Regulation Agencies & $\begin{array}{l}\text { To regulate the "local piped gas services" provided by the LDC (Local } \\
\text { Distribution Companies). }\end{array}$ \\
\hline $\begin{array}{l}\text { Energy Research Company } \\
\text { (Empresa de Pesquisa Energética-EPE) }\end{array}$ & $\begin{array}{l}\text { To provide services in the area of studies and research destined to subsidize } \\
\text { planning in the energy sector. }\end{array}$ \\
\hline
\end{tabular}

Source: prepared by author. 
To achieve that, each public agency of the energy sector must perform its role as prescribed in the legal framework. Thus, the CNPE should establish guidelines for specific programs, such as those for biofuel use, and propose policies for the use of local resources, which can stimulate local biogas production and use. However, this agency has not had a proactive role in proposing policies.

Another important element is the interaction between the different Ministries of State involved in biogas production and use. In order to achieve that, the Ministry of Agricultural Development (focused on small rural properties), the Ministry for the Environment (focused on waste treatment and environmental protection), and the Ministry of Mines and Energy should make a joint effort to allow the CNPE to propose policies that facilitate the inclusion of biogas as an energy source, both for thermal energy and electricity.

With regard to planning, the EPE should consider in its agenda the real potential of biogas, taking into account the environmental advantages derived from the proper management of animal waste and from distributed generation (avoided cost of expanding generation and transmission). Of course, the great complexity of Brazil's electrical system hinders the task of measuring and allocating these benefits, nevertheless, it must be completed.

As for regulation, despite juxtapositions in different legal frameworks, it is possible for federal and state regulators to reach an agreement to allow the creation of enterprises that can take advantage of local energy resources. Even without changes to legislation, programs, such as cooperative agreements between regulators, can be used in specific cases to secure private investments in biogas.

After the technological and bureaucratic issues are overcome, there is still the need to obtain financing for biogas enterprises. There are government institutions that can be used in this financing, i.e., Bank of Brazil, which has low interest rate loans for small rural enterprises, and the National Bank for Economic and Social Development (Banco Nacional de Desenvolvimento Econômico e Social-BNDES), which can finance investments in medium-size and large rural properties. It must be pointed out, however, that this is only one of the requirements for achieving the investments. The fundamental issue is to find a solution to the legal barriers, primarily through the coordination of the above mentioned agents. Finally, we can add to these agents the Brazilian Biogas Network (Rede Brasil Biogás), a network of technical, scientific, industrial, commercial, and agricultural exchange that revolves around the topic of biogas and the possible energies generated by its use for the purpose of stimulating the flow of knowledge on the topic and having the widest possible outreach through its members. Different spheres of government can interact with the Brazilian Biogas Network to better understand the peculiarities of the industry, thus leading to more focused and specific policies.

\section{Conclusions}

This article sought to demonstrate that, along with Brazil's enormous biogas generation potential, particularly through the transformation of animal waste, there is an important governmental agenda centered on legal, political, and regulatory challenges. The main elements that compose the government agenda have been presented to assist in the design of policies and actions that will increase distributed generation of biogas and/or electricity derived from biogas, obtained from residual biomass by sanitary and environmentally acceptable means, for private use and sale of possible excess of gas and/or electricity.

As previously emphasized in this study, this biogas (or the electricity derived from it) is destined primarily for private use in rural properties with immediate positive results in terms of the environment and the avoided cost of investments in the natural gas and energy sectors. In the country's southern region, for example, which has the largest production of swine and 
confined cattle, the consumers of the excess biogas can be businesses located near the generating units. In 2011, the industrial demand for natural gas increased by $8 \%$ compared to 2010 , particularly in the ceramics $(12.9 \%)$, pig iron and steel (11.2\%), and chemical (6.4\%) sectors [1]. Brazil's white ceramics industry is also concentrated in the region and is a potential consumer of biogas.

The article has presented a long list of challenges, the greatest being the development of an energy policy that will allow the consistent introduction of this "alternative" source of energy into the national energy grid, as established by Law 9478/97. This same law states that one of the principles and objectives of the national energy policy is to "increase the participation of biofuels in the national energy grid on an economic, social, and environmental basis".

In fact, the challenges presented in the governmental agenda can be analyzed in two phases. In the first phase, the governmental agenda must create incentives for biogas production aimed at environmental care through the treatment of residual biomass and at energy generation (biogas and electricity) for private consumption. In a potential second phase, with more developed biogas systems and resolved technical and financial issues, it would be possible to encourage the sale of biogas excess to natural gas and/or electricity distribution networks. This phase is apparently more complex and requires more time for implementation.

In the academic sphere, a useful tool that should be addressed in relation to biogas is the use of a GIS (Geographical Information System), given that the majority of enterprises represent distributed generation (of gas or electricity). The regional aspect is, therefore, of fundamental importance, and local governments must be mindful of the potential for production and use of this renewable energy source.

\section{References}

[1] Brasil. 2013. Brazilian Energy Balance 2012, Empresa de Pesquisa Energética. Accessed November 12, 2013. https://ben.epe.gov.br/downloads/Relatorio_Final_BEN_ 2013.pdf.

[2] Simas, M., and Pacca, S. 2011. "Windpower Contribution to Sustainable Development in Brazil." In Proceedings of World Renewable Energy Congress, 2626-33.

[3] Salomon, K. R., and Lora, E. S. 2005. "Energetic Potential Estimate for Electric Energy Generation of Different Sources of Biogas in Brazil." Viçosa, Revista Biomassa \& Energia 2 (1): 57-67.

[4] Hachisuca, A. M. M., Fernandes, D. M., Silva, F. P., Antunes, M. A., Leonardo, P. C. A. S., Costanzi, R. N., and Akaboci, T. R. V. 2010. Geração distribuída: biomassa residual utilizada como fonte de energia alternativa em unidades de demonstração. Belém, III Simpósio Brasileiro de Sistemas Elétricos.

[5] Srinivasan, S. 2008. "Positive Externalities of Domestic Biogas Initiatives: Implications for Financing." Renewable and Sustainable Energy Reviews 12 (5): 1476-84.

[6] Lantz, M., Svenssonb, M., Bjornsson, L., and Borjesson, P. 2007. "The Prospects for an Expansion of Biogas Systems in Sweden - Incentives, Barriers and Potentials." Energy Policy 35 (3): 1830-43.

[7] Bley, J. R. C., Libanio, J. C., Galinkin, M., and Oliveira, M. M. 2009. Agroenergia da biomassa residual: perspectivas energéticas, socioeconômicas e ambientais. FAO. Accessed October 31, 2013. https://www.fao.org.br/download/agroenergia_biomassa_ residual251109.pdf.

[8] Fernandes, D. M. 2012. "Biomass and Biogas Pig Farming." M.Sc. dissertation, Universidade Estadual do Oeste do Paraná.

[9] Karellas, S., Boukis, I., and Kontopoulos, G. 2010. "Development of an Investment Decision Tool for Biogas Production from Agricultural Waste." Renewable and Sustainable Energy Reviews 14 (4): 1273-82.

[10] IBGE. 2007. Censo Agropecuário 2006. Brasil, grandes regiões e unidades da federação. Rio de Janeiro: IBGE.

[11] IBGE. 2009. Censo Agropecuário 2006. Agricultura Familiar: grandes regiões e unidades da federação. Rio de Janeiro: IBGE.

[12] Bley, J. R. C. 2010. Reflexões sobre a economia do biogás. Foz do Iguaçu, Itaipu Binacional.

[13] Salomon, K. R. 2007. "Technical-Economic and Environmental Assessment of the Use of the Biogás from Biodigestion Vinasse in Electricity Generating Technologies." D.Sc. thesis, Universidade Federal de Itajubá, Itajubá.

[14] Mathias, J. F. C. M. 2014. "Manure as a Resource: Livestock Waste Management from Anaerobic Digestion, Opportunities and Challenges for Brazil.” In International Food and Agribusiness Management Review, 87-110. 
[15] Jiang, X., Sommer, S. G., and Christensen, K. V. 2011. “A Review of the Biogas Industry in China." Energy Policy 39 (10): 6073-81.

[16] Castanon, N. J. B. 2002. Biogas Produced from Farm Waste. São Paulo: Universidade de São Paulo.

[17] Bond, T., and Templeton, M. R. 2011. "History and Future of Domestic Biogas Plants in the Developing World." Energy for Sustainable Development 15 (4): 347-54.

[18] Cervi, R. G., Esperancini, M. S. T., and Bueno, O. C. 2010. "Economic Viability for Electrical Power Generation Using Biogas Produced in Swine Grange." Engenharia Agrícola 30 (5): 831-44.

[19] Mathias, J. F. C. M., and Mathias, M. C. P. P. 2012. "Biogas in Brazil: Opportunities and Challenges."
Presented at the Rio Oil \& Gas Expo and Conference, Rio de Janeiro.

[20] Coldebella, A. 2006. "Viability of Using Biogas from Cattle and Swine Culture to Generate Electricity and Irrigation.” M.Sc. dissertation, Universidade Estadual do Oeste do Paraná.

[21] Ferreira, M., Marques, I. P., and Malico, I. 2012. "Biogas in Portugal: Status and Public Policies in a European Context." Energy Policy 43 (Apr.): 267-74.

[22] Pereira, O. L. S. 2009. "Renewable Energy as a Tool to Assure Continuity of a Low Emission Brazilian Electric Power Sector-Results of an Aggressive Renewable Energy Policy." In Proceedings of IEEE 2009 Power \& Energy Society General Meeting, 1-7. 